\title{
Appendix 1
}

A message on the marriage referendum: 'Care for the covenant of marriage’ by Archbishop Eamon Martin.

To interfere with the definition of marriage is not a simple or a trivial matter - Archbishop Martin

On 22 May 2015 a referendum will take place in the Republic of Ireland on the introduction of same-sex marriage. Archbishop Eamon Martin, Archbishop of Armagh and Primate of All Ireland said in a statement:

In recent weeks and months I have received many letters and messages asking me, as a Bishop, to explain clearly the Church's teaching on marriage in the context of the forthcoming referendum. The Irish bishops have already said that we cannot support an amendment to the Constitution which redefines marriage and effectively places the union of two men, or two women, on a par with the marriage relationship between a husband and wife which is open to the procreation of children.

The Church's vision for marriage and the family is based on faith and reason and it is shared by many people of all faith traditions and none. Since time immemorial, Church and State have recognised marriage to be of fundamental importance for children, mothers and fathers, and society. To interfere with the definition of marriage is not a simple or a trivial matter.

The teaching of the Catholic Church on the issue of same-sex unions was reiterated at the Extraordinary Synod on the Family in Rome, 2014: 'There are absolutely no grounds for considering homosexual unions to be in any way similar or even remotely analogous 
to God's plan for marriage and family' (Synod Report n55). At the same time, the Church emphasises that gay people ought always to be treated with respect and sensitivity.

\section{The 'dignity of difference' between male and female}

As people of faith, we believe that the union of a man and a woman in marriage, open to the procreation of children, is a gift from God who created us 'male and female'. But we are also people of reason, who hold to the truth about human sexuality, grounded in the natural law, that the relationship between a man and a woman is unique.

How have we got ourselves into the situation that when people stand up to guard the dignity of difference between a man and woman, and speak for the traditional definition of marriage, they are often portrayed as being against freedom, or against equality? How is it that many people won't even raise these issues in their families and workplaces for fear of being ridiculed or condemned as homophobic? Could we not expect at least some of our legislators to engage in public discussion on both sides of this debate?

Until now, Ireland has accepted that it is in the best interests of children and of society to promote and protect the model of children being born and raised in a family with their biological parents. The proposed amendment to the Constitution will remove the unique and privileged status in society for the marriage between a man and a woman. It is worth noting what Pope Francis has said recently: 'When the stable and fruitful covenant between a man and a woman is devalued by society, it is a loss for everyone, especially the young' (General Audience 22nd April 2015).

\section{Care for the covenant of marriage - Pope Francis}

We read in the Book of Genesis that from the beginning, God created human beings in His own image - 'male and female' - and commissioned them to 'be fruitful'. Marriage is willed by God, and instituted and sanctified by God, to be the way in which God's work of creation continues in the world. The gift of life, which flows from the intimate union of a man and woman in marriage, is a gift from God Himself. 
Catholics give marriage the dignity of a 'sacrament' because it mirrors the mystery of God's love for humans and of Christ's love for His Church. Pope St John Paul II, who is remembered as the 'Pope of the Family' described marriage as the 'primordial sacrament' - in the sense that it is the original and most ancient sacrament which belongs to creation itself. In April, Pope Francis reminded us that marriage is a 'noble vocation' and he urged all of us to care for the 'covenant' of marriage between man and woman.

The gift of life, which flows from the intimate union of a man and woman in marriage, is a gift from God Himself.

\section{A misunderstanding of 'equality'}

What makes marriage unique among other types of relationship is the distinctiveness of the union between a man and a woman which is open to life. To remove this specific difference is not, as some would argue, a development or evolution of our understanding of marriage; it is, rather, a very definite break with human history and with the natural institution of marriage. We end up using the term 'marriage' for something that it is not. Many of the arguments being made for the proposed amendment appear to be based on a misunderstanding of 'equality'. It is a fact of nature that same-sex unions are fundamentally and objectively different from the complementary sexual union of a woman and a man which is, of itself, naturally open to life.

During the current debate we are conscious of same-sex partners who love each other and wish to share their life together. 'Marriage' is about much more than a loving relationship between consenting adults. Marriage has another essential element - the openness to children who are born of the love and sexual relationship of their mother and father. This is why, as Article 41:3:1 of the Constitution puts it: 'The State pledges itself to guard with special care the institution of Marriage, on which the Family is founded, and to protect it against attack.' The State encourages and favours the marriage of a man and a woman, open to children, because it is for the common good. It not only satisfies individual love and needs, but it also ensures the future of society and forms the ideal environment for the development of children.

We know, of course, that, as Pope Francis put it recently: 'A perfect family does not exist'. Many families experience great trials, 
and struggle with wounded relationships and disappointments. Tensions and loneliness can build up within the home. The marriage relationship does not always 'work out' as hoped for. Sadly, and despite their best intentions, many married couples separate, often for the good of their children and for their own well-being. We also know that many parents are generously and successfully raising children on their own, and many others are giving great love and joy to children through adoption and fostering. This does not mean, however, that we should not continue to hold up the example of a faithful, life-long and committed marriage relationship between a man and a woman as something beautiful and special. Society should do everything in its power to support and encourage this unique union so that as many children as possible can have a father and a mother who live together in a relationship marked by stability and love.

What makes marriage unique among other types of relationship is the distinctiveness of the union between a man and a woman which is open to life.

\section{Freedom of conscience}

Some commentators have said that 'sacramental' or 'religious' marriage is not affected by the proposed amendment. It is important to remember that religious freedom means much more than simply the freedom to worship or have ceremonies of a particular type. Freedom of religion is linked very closely to freedom of conscience and freedom to express publicly our values and beliefs in daily life.

If society adopts and imposes a 'new orthodoxy' of 'gender-neutral' marriage, being defined simply as a union between any two persons including a man and a man, or a woman and [a] woman - then it will become increasingly difficult to speak or teach in public about marriage as being between a man and a woman. Will there be lawsuits against individuals and groups who do not share this vision? What will we be expected to teach children in school about marriage or about homosexual acts? Will those who continue to sincerely believe that marriage is between a man and a woman be forced to act against their faith and conscience?

Freedom of religion is linked very closely to freedom of conscience and freedom to express publicly our values and beliefs in daily life. 


\section{Reflect and pray before you vote}

I encourage everyone to reflect and pray carefully about these issues before voting on 22 May. It is very important to vote. Do not be afraid to speak up courageously for the union of a man and a woman in marriage.

Pope Francis reminds us: 'While a noble vocation, marriage is not an easy one: it must constantly be strengthened by a living relationship with the Lord through prayer: mornings and evenings, at meals, in the recitation of the Rosary, and above all through the Sunday Eucharist.'

I invite you, especially in May, the month of Mary, to pray the Rosary for all the families of Ireland, remembering those who are especially in need of prayer at this time. May our families be models of faith, love and generous service.

\section{Prayer to the Holy Family}

Jesus, Mary and Joseph, in you we contemplate the splendour of true love, to you we turn with trust.

Holy Family of Nazareth, grant that our families too may be places of communion and prayer, authentic schools of the Gospel and small domestic Churches.

Holy Family of Nazareth, may families never again experience violence, rejection and division: may all who have been hurt or scandalised find ready comfort and healing.

Holy Family of Nazareth, may the approaching Synod of Bishops make us once more mindful of the sacredness and inviolability of the family, and its beauty in God's plan.

Jesus, Mary and Joseph, graciously hear our prayer. Amen.

Source: Irish Catholic Media Office, released 2 May 2015. 